\title{
The Compression of Granulates
}

\section{Granüllerin Kompresyoni}

\author{
E. SHOTTON* and Oya ALPAR**
}

\section{Introduction}

Granulation is the aggregation of smalt solid particles of form larger masses having desirable physical properties. The mechanism underlying aggregation have been described by Rumpf (1) and in pharmaceutical granulations surface tension forces and the formation of crystalline bridges, when solvents are used, are probably the two major mechnaisms. The effect of moisture on the compression characteristics of powders and granules has been investigated by Seth and Munzel (2), Jaffe and Moss (3) and by Shotton and Rees (4). In addition, Shotton and Rees examined the effect of the presence of a solvent (water) and non-solvents (light liquid paraffin and decahydronaphthalene) on the compaction of sodium chloride crystals. Very little has been carried out on the effect of granulating powders with volatile solvents and non-solvents and the subsequent compression of the dried granules.

\section{MATERIALS AND METHODS.}

Aspirin B.P. and hexamine B.P. These substances were ballmilled and the resulting powders classified with an Alpine Multiplex zigzag classifier $100 \mathrm{MZR}$, and the fraction having a particle size of $3 \mu \mathrm{m}$ chosen. The material collected was passed through the classifier a second time to remove undersized particles.

Redaksiyona verildiği tarih: 1 Nisan 1974

(*) Department of Pharmaceutics, The School of Pharmacy, University of London, Brunswick Square, LONDON, WGIN LAX, England.

(*). Hacettepe Universitesi, Eczacilik Fakültesi Gaienik Farmasi Bölümü, ANKARA; Turkey. 
Spray-dried lactose. The lactose was passed through of fluid energy mill and on subsequent microscopic size analysis the weighmean diameter was found to be $2 \mu \mathrm{m}$.

Sulphadiazine. A commercial powder of B.P. quality was obtained and a size analysis carried out using a Coulter Counter. The mean particle size was found to be $3 \mu \mathrm{m}$.

Granulating liquids. The following volatile liquids, absolute alcohol, diethyl ether, acetone and distilled water, were used. For each substance a granulating liquid was chosen in which the substance had the greater solubility, granulate A, and another liquid in which the substance was much less soluble, granulate B. The liquids chosen for each powder are given in Table 1 . Where substances have a low solubility in the liquid it was considered unlikely that, on evaporation, significant crystalline bridges would be formed. The choice of liquids was limited and the liquid in which the substance had the greater solubility was termed the "solvent», the distinction to some extent being arbitrary.

Granulation. The granules were prepared by moistening the powder with the chosen liquid in a mortar and then presing the moistened mass through a sieve. The moist granules were dried in an oven at $50^{\circ} \mathrm{C}$ for the non-aqueous liquids and at $75^{\circ} \mathrm{C}$ for granules prepared with distilled water. The amount of liquid was just enough to wet the powder mass, although the quantity of ether and acetone was large due to evaporation.

The dried granules were again sieved and the following fractions collected; $-10+20$ mesh, $-20+30$ mesh, $-30+40$ mesh, $-40+60$ mesh. These gave mean particle sizes as; $1245 \mu \mathrm{m}, 717$ $\mu \mathrm{m}, 507 \mu \mathrm{m}$ and $335 \mu \mathrm{m}$ respectively. Microscopic examination confirmed that the granules in the fractions were uniform and free form fines. The hardness of the granules was assessed arbitrarily by crushing under a steel spatule (Ganderton and Selkirk (5). 


\begin{tabular}{|c|c|c|c|c|c|c|}
\hline \multirow[b]{2}{*}{ Substance } & \multicolumn{3}{|c|}{ "Granulate A" } & \multicolumn{3}{|c|}{ «Granulate B } \\
\hline & $\begin{array}{l}\text { Solubility in } \\
\text { liquid } w / v\end{array}$ & $\begin{array}{l}\text { Quantity } \\
\text { per } 100 \mathrm{~g} \\
\text { of Power }\end{array}$ & $\begin{array}{l}\text { Friability } \\
\text { under } \\
\text { spatula }\end{array}$ & $\begin{array}{l}\text { Solubility in } \\
\text { liquid } w / v\end{array}$ & $\begin{array}{l}\text { Quantity } \\
\text { per } 100 \mathrm{~g} \\
\text { of Powder }\end{array}$ & $\begin{array}{l}\text { Friability } \\
\text { under } \\
\text { spatula }\end{array}$ \\
\hline Hexamine & $\begin{array}{l}\text { Distilled } \\
\text { water } \\
1 \text { in } 1.5\end{array}$ & $4 \mathrm{ml}$ & very hard & $\begin{array}{l}\text { Ether } \\
1 \text { in } 320\end{array}$ & $50 \mathrm{ml}$ & medium hard \\
\hline Aspirin & $\begin{array}{l}\text { Alcohol } \\
\text { Absolute } \\
1 \text { in } 5 \\
\end{array}$ & $20 \mathrm{ml}$ & medium harc & $\begin{array}{c}\text { Distilled } \\
\text { water } \\
1 \text { in } 300 \\
\end{array}$ & $40 \mathrm{ml}$ & soft \\
\hline Sulphadiazine & $\begin{array}{l}\text { Acentone } \\
1 \text { in } 300\end{array}$ & $56 \mathrm{ml}$ & soft & $\begin{array}{l}\text { Distilled } \\
\text { water } \\
\text { lin } 13 \times 10^{3} \\
\end{array}$ & $62.4 \mathrm{ml}$ & saft \\
\hline $\begin{array}{l}\text { Spray-dried } \\
\text { Lactose }\end{array}$ & $\begin{array}{l}\text { Distilled } \\
\text { water } \\
1 \text { in } 6\end{array}$ & $12 \mathrm{ml}$ & very hard & $\begin{array}{l}\text { Absolute Alcohol } \\
\text { (almost } \\
\text { insoluble) }\end{array}$ & $34 \mathrm{ml}$ & very soft \\
\hline
\end{tabular}

TABLO 1 : Substances and liquids used for Granulations 


\section{Moisture Content}

The residual liquid, referred to as the moisture content of the dried granules, was determined with a Chan Gram Electrobalance in a vacuum oven and in each case was below $0.04 \% \mathrm{w} / \mathrm{w}$, so that the effect of liquid present on the compression characteristic of the granules was minimal.

\section{Compression of Granules}

The weight of granules required to give each taglet $4 \mathrm{~mm}$ thick at zero porosity was filled into the die in each case. The weighed granules were left in desiccators over night the moisture content then determined. Plane faced cylindrical punches, $12 \mathrm{~mm}$ diamer, were used. Tablets were compressed from the granules at four different force levels and five tablets were produced at each force level. A power-driven Lehmann tablet machine was used, instrumented in a manner similer to that described by Shotton and Ganderton (6) and a constant speed setting on the Kopp variator was used throughout. The bore of the die and the punch tips were cleaned before each compression with metal polish and degreased with acetone. For sulphadiazine, to avoid jamming the machine the die and punches were lubricated by painting with a $2 \%$ solution of stearic acid in acetone-carbon tetrachloride (1:1), and alloving to evaporate before the compaction of each tablet. The tablets were weighed, the thickness measured and the crushing strength determined by the method of Shotton and Ganderton (6). From the dimensions the relative volume and relative density were calculated.

\section{R E S U L T S}

The results of the crushing strength, $\mathrm{Fc}$, of tablets, are summarised in Figures 1, 2, 3, 4, 5 and 6. The verticle bars in figures indicate \pm one standard deviation. 


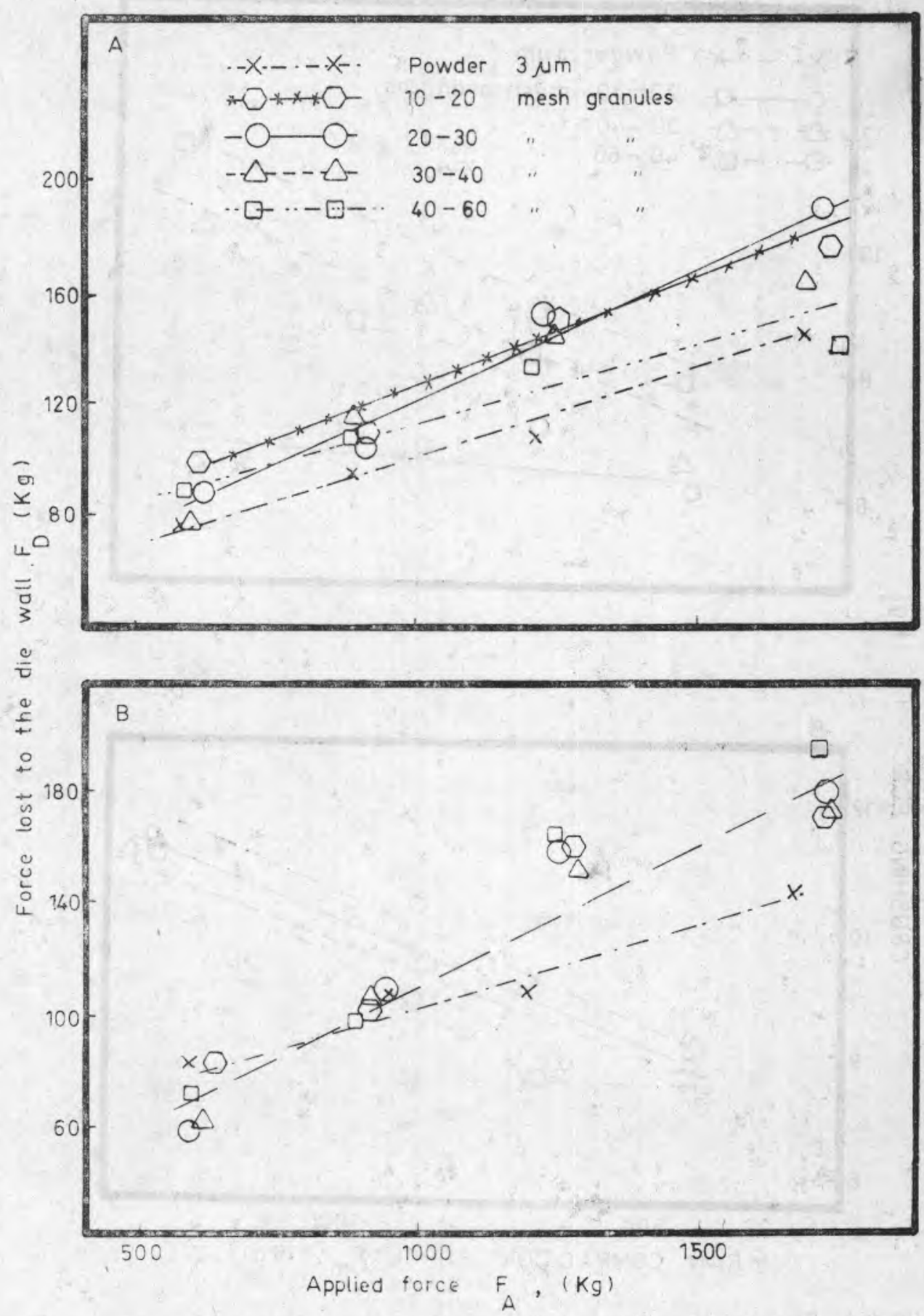

FIG. 1. The strenght of hexamine compacts prepared from granulates A. and $\mathrm{B}$. 


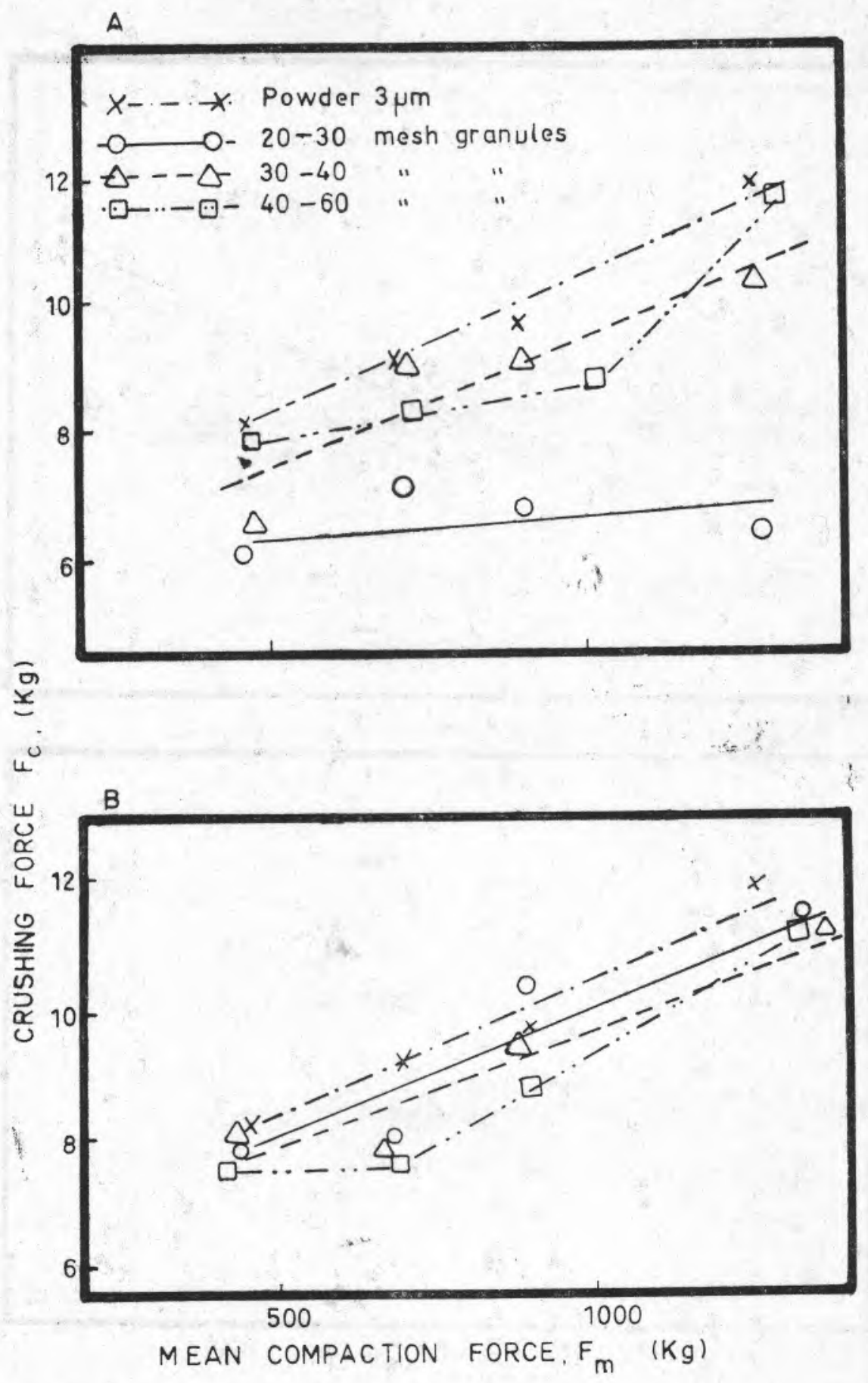

FIG. 2. The stength of aspirin tablets prepared from,
A) Granules A.
B) Granules B. 


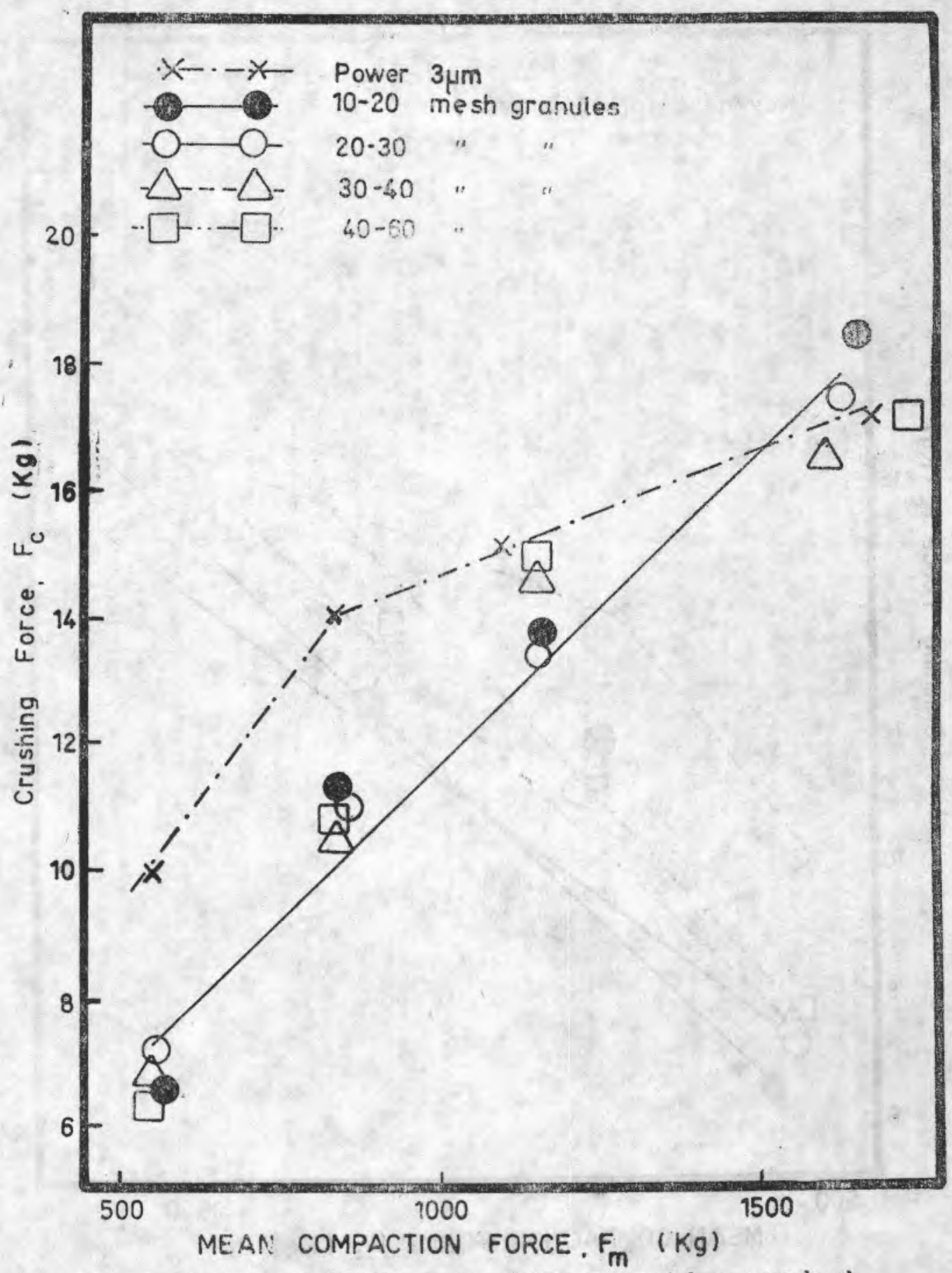

FIG. 3. The strength of sulphadiazine tablets prepared from granules A, 


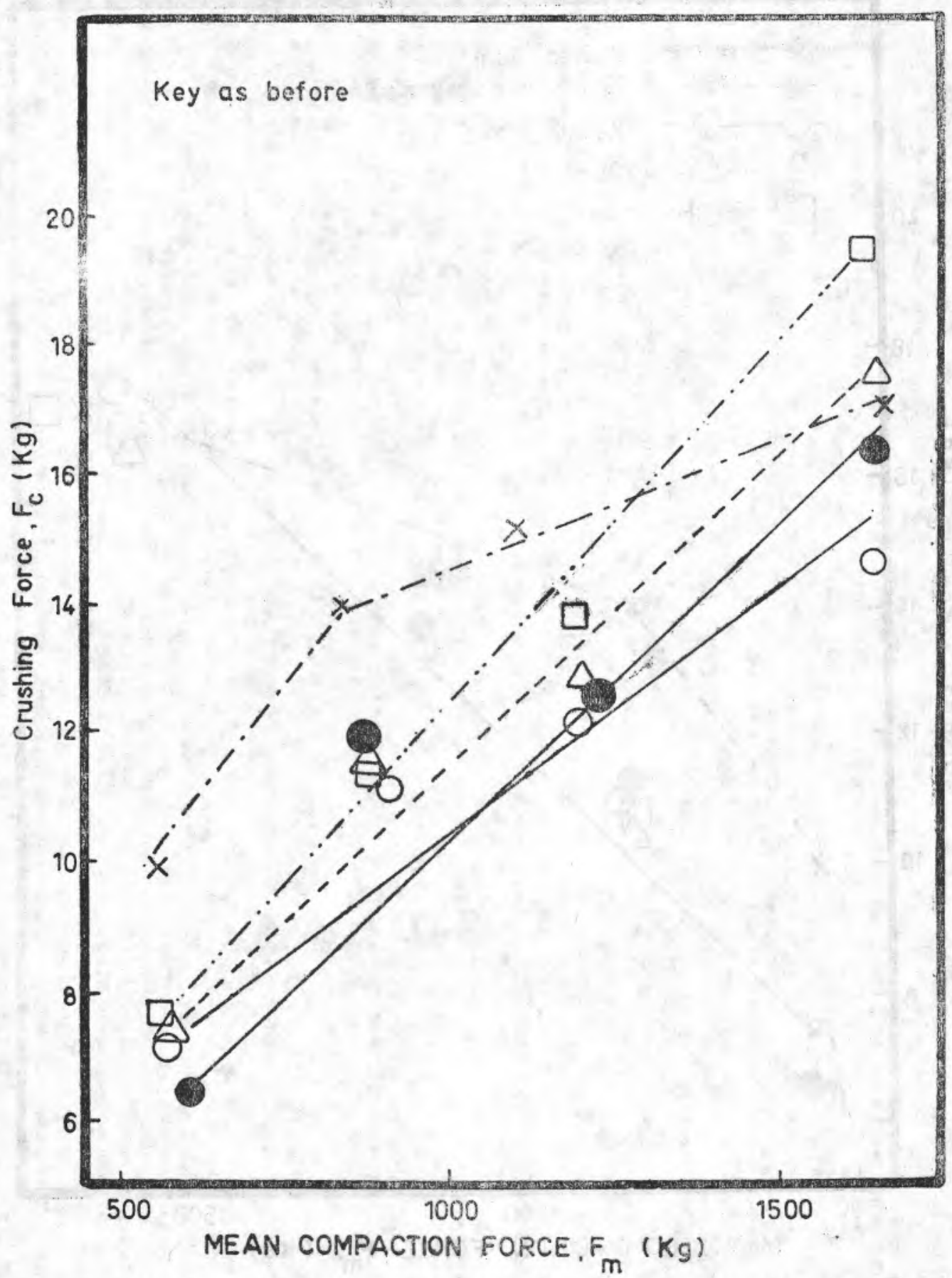

FIG. 4. The strength of tablets of sulphadiazine prepared from granules B. 


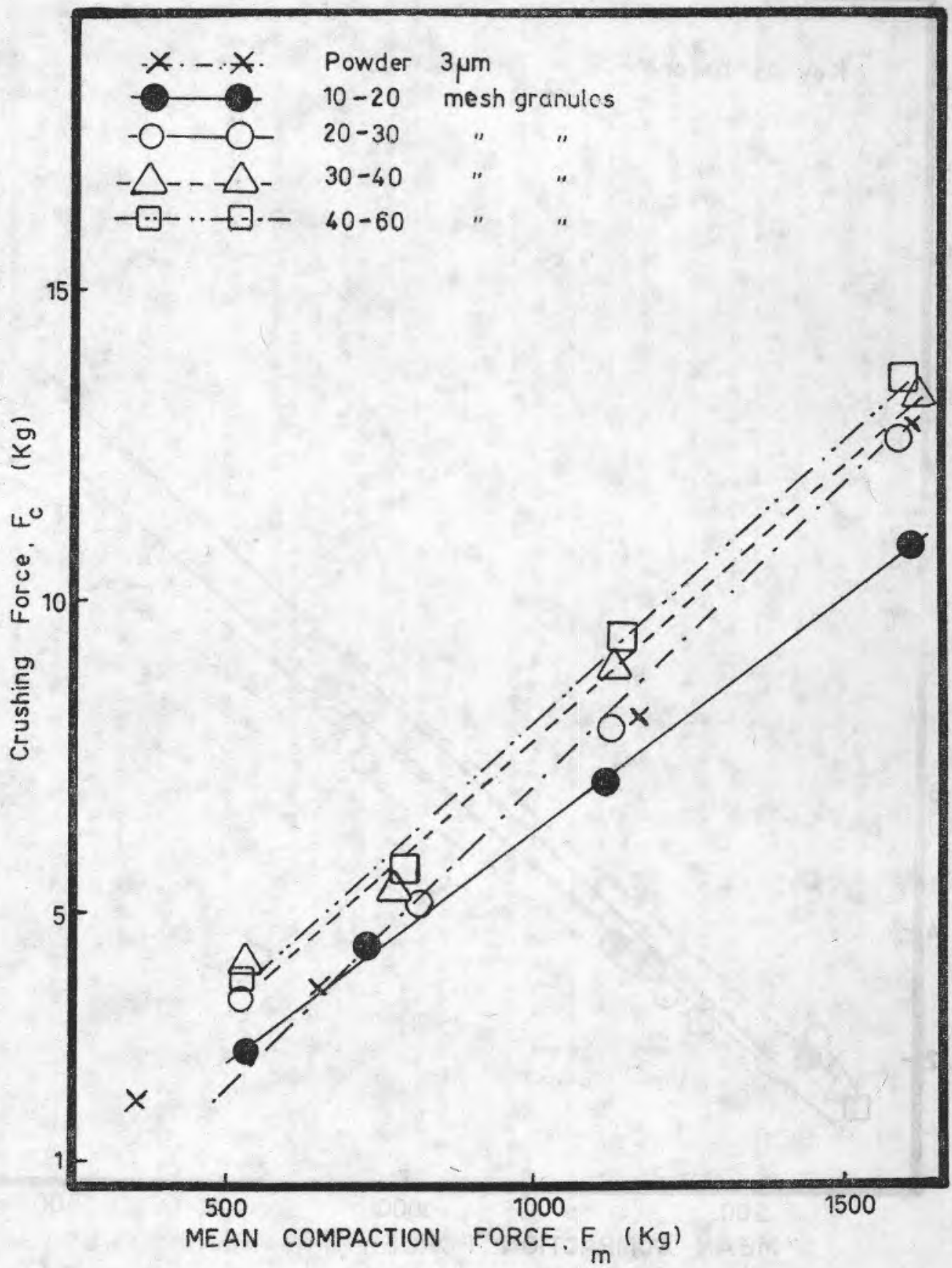

FIG. 5. The strength of spray - dried lactose tablets prapared from gra nules A. 
Key as before

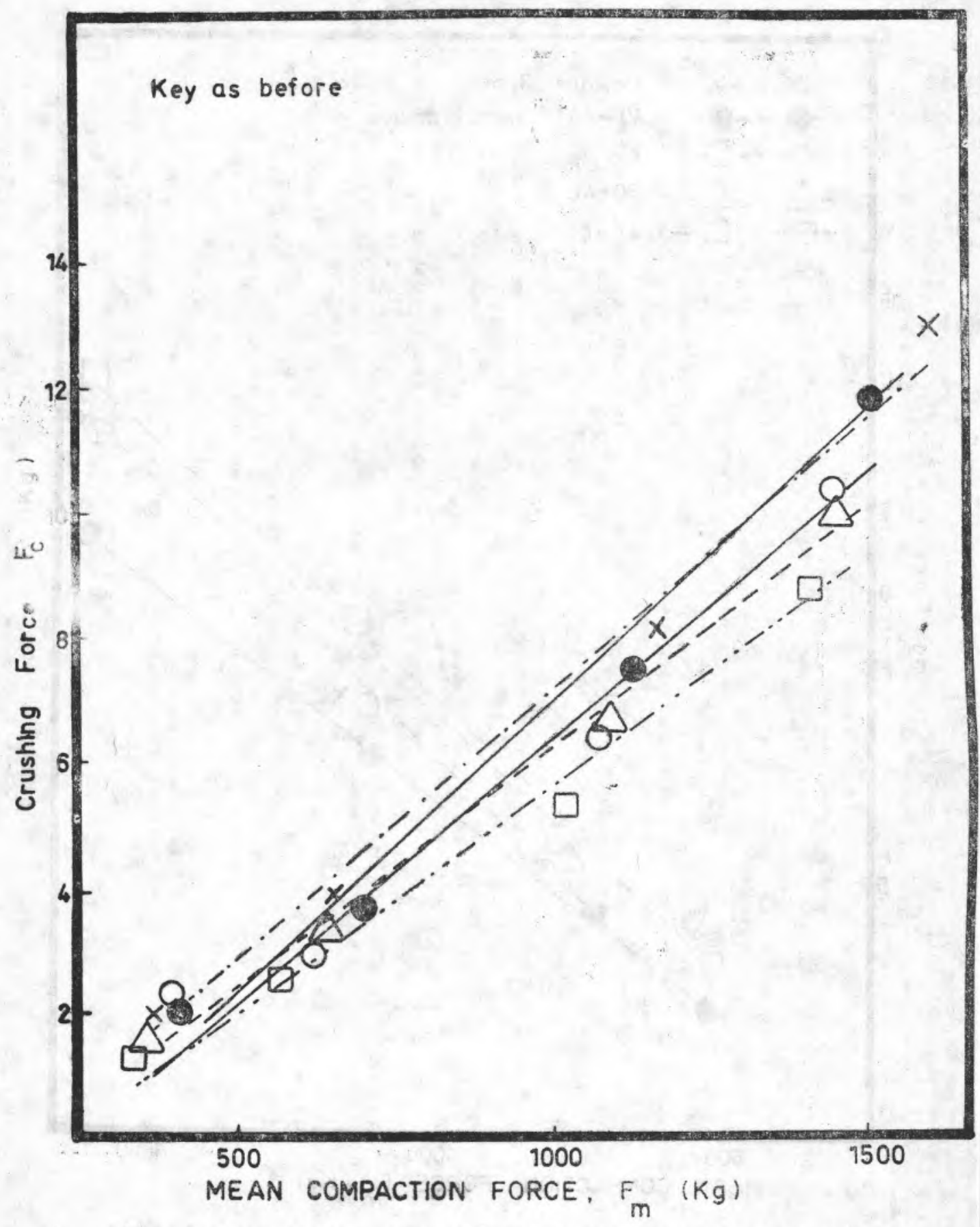

FIG. 6. The strength of spray-dried lactose tablets prepared from granules B. 


\section{Effects of granulating liquid}

Granules formed by using a liquid in which the substance haci the greater solubility (granulates A) were harder than the granu lates B.

At low compression pressures the effect of the granules on tablet strength and other parameters was inconsistent due to smali plastic distortion and fracture of the granules. The effects were more consistent at the higher pressures used. The tablets compres sed from granulates A were stronger than tablets prepared trom granulates B for aspirin, sulphadiazine and spray-dried lactose. With hexamine the strength of the tablets was little difterent whether granules A or granules B were used.

The effect of granule size was variable. With hexamine the granule size had little effect on tablet strength whether solvent or non-solvent was used for granulation, except that the largest gri nules A gave the weakest tablets. With aspirin the largest granules gave the strongest tablets for both granulates A and granulates B. The strongest sulphadiazine tablets were produced from the smallest granules when granulates B were compressed, whereas for granulates A the effect of granule size was negligible.

Finally with the spray-dried lactose the strongest tablets we. re formed from the largest granules when granulates B were used. This is the reverse of the effect using sulphadiazine B granules and also the reverse of the effect when compressing spray-dried lactose A granules.

Force lost to the die wall, Figs. 7, 8, 9, 10, 11 and 12.

Aspirin. The force transmitted to the bottom punch was greater (i.e. Fd was less) for the granulate B than for the granulat A. In both cases however, there was a tendency of an increasing transmitted force ( $\mathrm{Fd}$ decreased) as the granule size increased and the original powder showed the greatest value for $\mathrm{Fd}$ at the higher levels. 


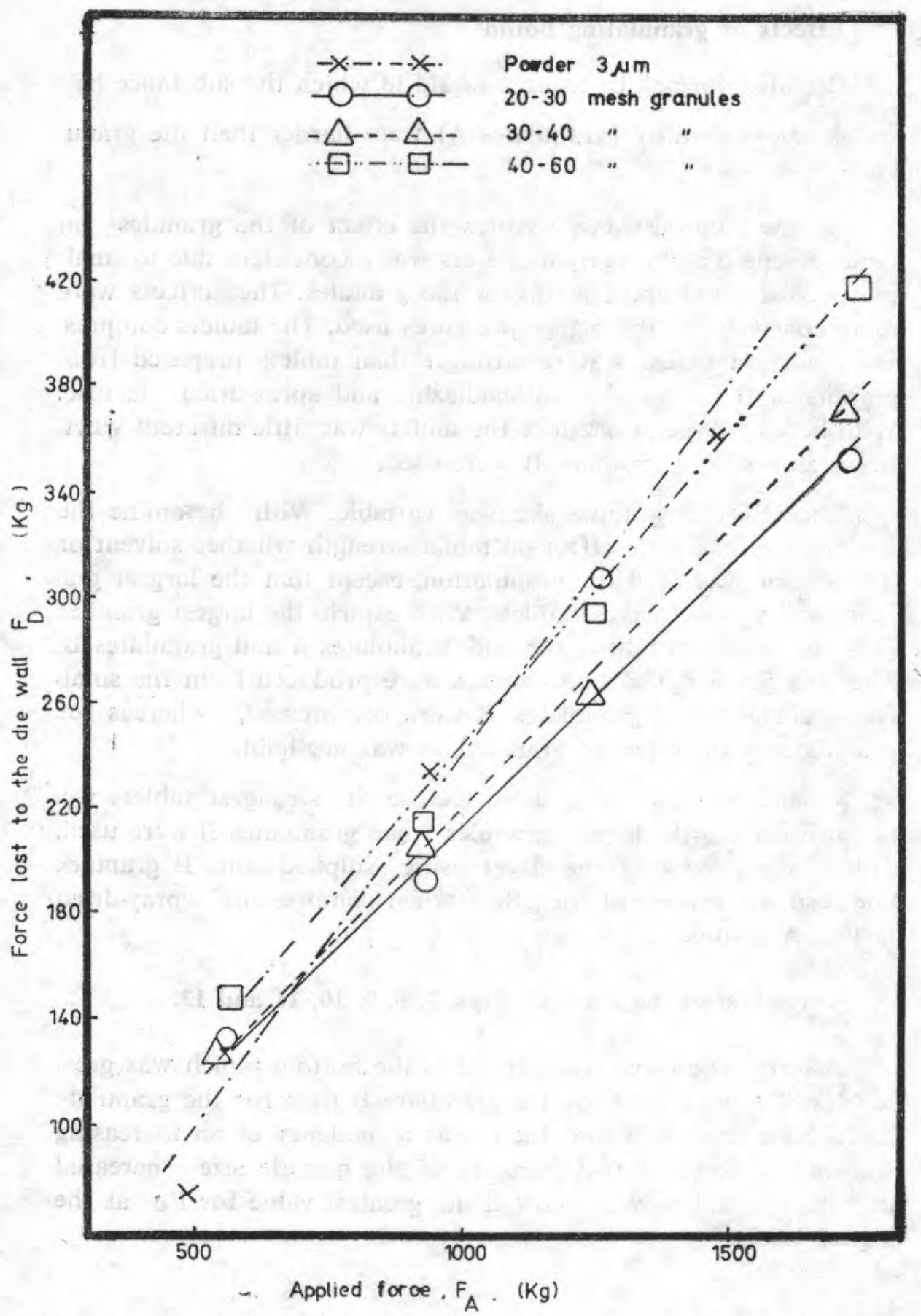

FIG. 7. The effect of applied fofrce on the force lost to the die wall when aspirin $(3 \mu \mathrm{m})$ granules $A$ were used. 


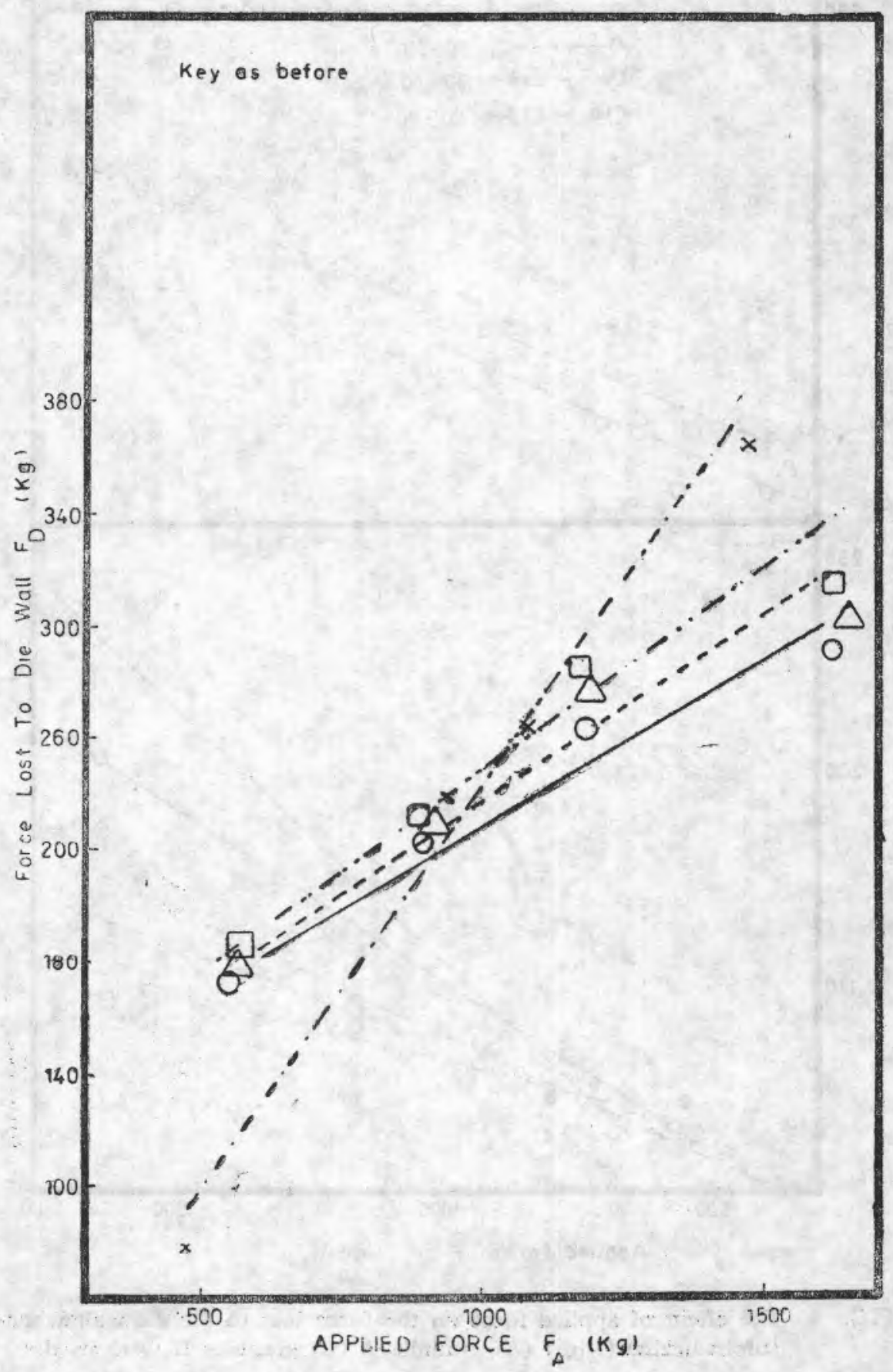

FIG. 8. The effect of applied force on the force lost to the die wall when aspirin $(3 \mu \mathrm{m})$ granules B were used. 


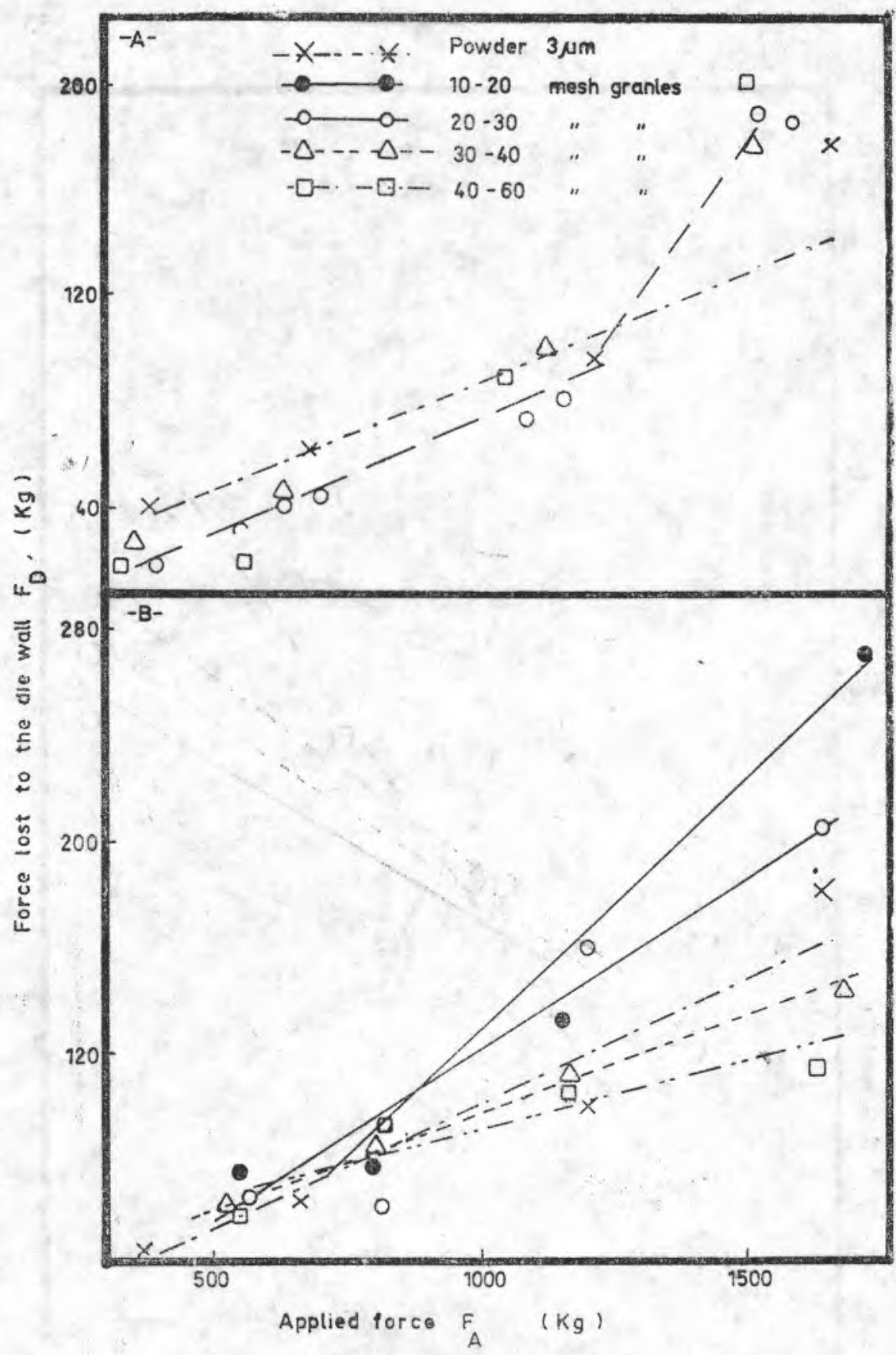

FIG. 9. The effect of applied force on the force lost to the die wall when sulphadiazine $(3 \mu \mathrm{m})($ A) granules A (B) granules B were used. 
$A$
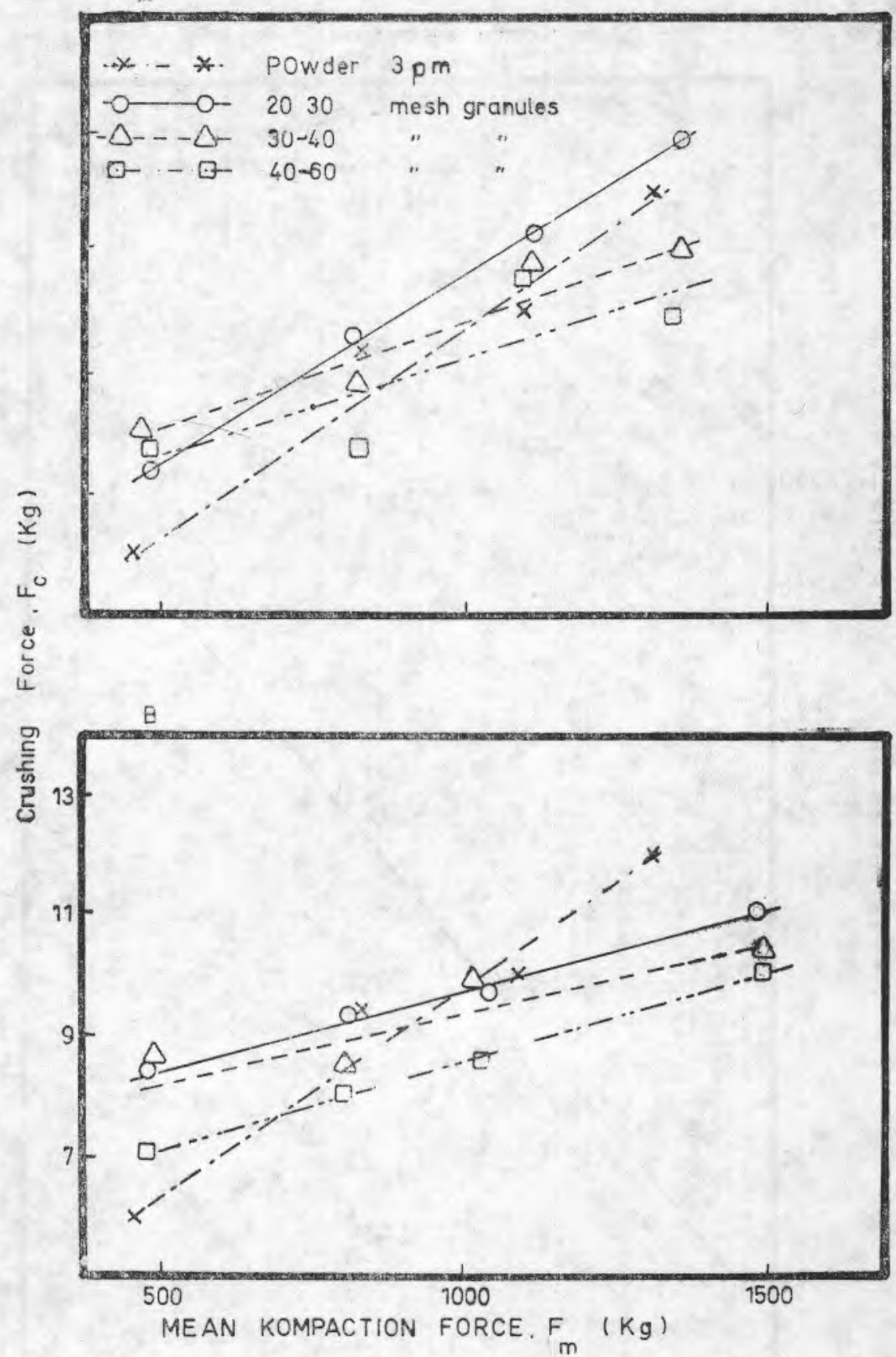

FIG. 10. The effect of applied force cn the force lost to the die wall when spray-dried lactose $(2 \mu \mathrm{m})(\mathrm{A})$ granules A (B) granules B weic used. 


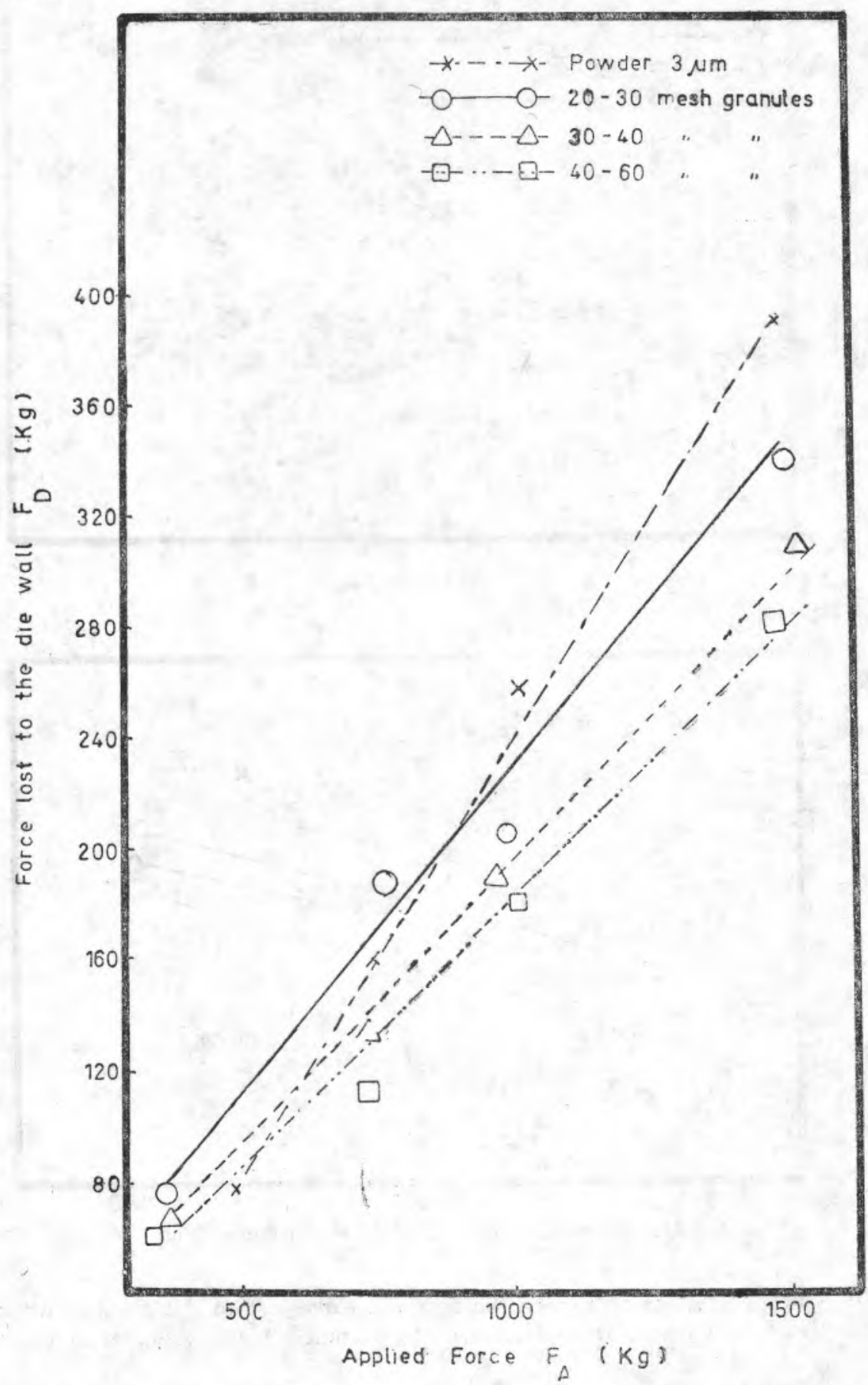

FIG. 11. The effect of applied force on the force lost to the die wal with hexamine A granules. 


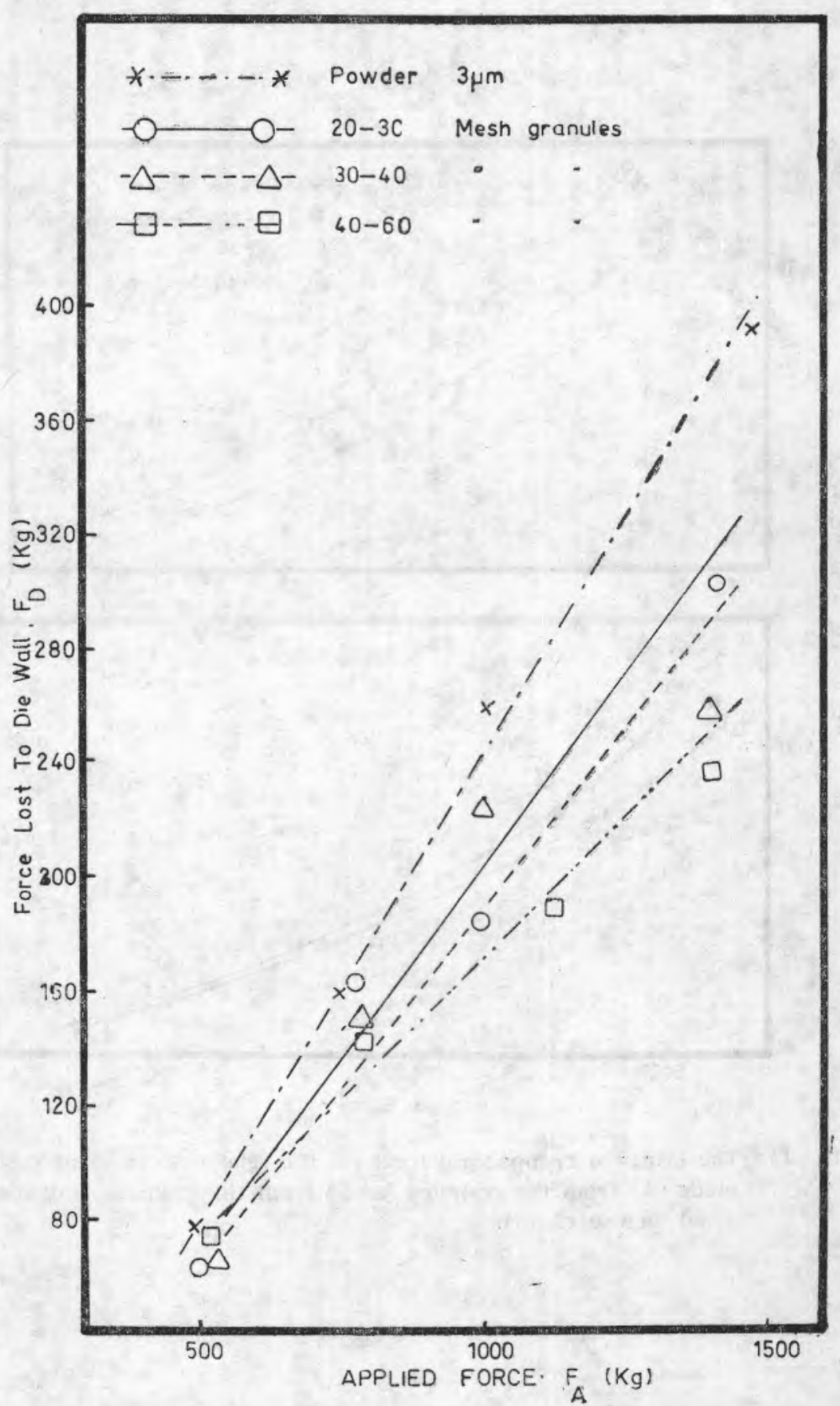

FIG. 12. The effect of applied force on the force last to the die wal with hexamine B granules. 


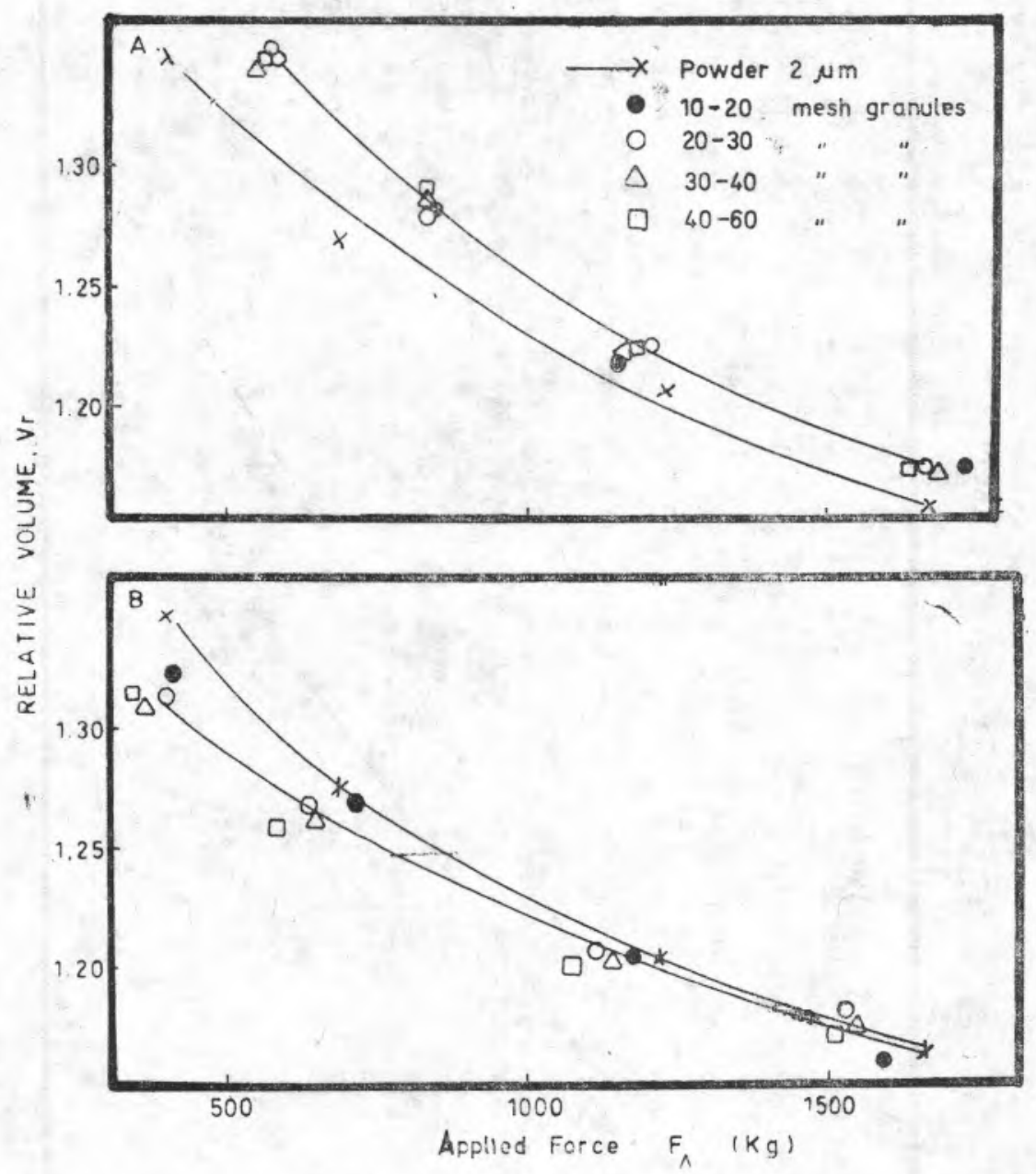

FIG. 13. The effect of compaction force on the relative volume of tablets. made (A) from the granules A, (B) from the granules B of spray dried lactose $(2 \mu \mathrm{m})$. 
Sulphadiazine. The force lost to the die wall (F d ) was similar for both types of granules an in both cases was greater than when the original powder was compressed. At the lowest pressure the force lost to the die wall was greatest for the original powder than for the granules B.

Hexamine. For tablets compressed from granules A of hexamine the effect of the applied force on the force lost to the die wall (Fig. 11) shows a decrease when compared to the tablets compressed directly from the powder. The effect of granules B of hexamine on the force lost to the die wall, Fd, was the same as found with the granules A of hexamine, only to a lesser extent. (Fig. 12).

Spray-dried lactose. For the granules B granule size had very little effect on the force lost to the die wall. For the granules A the force lost to the die wall was greatest for the largest granules.

The relative volume was calculated from the dimensions of the tablet immediately after ejection. This was found to be slightly less for tablets compressed from granules than from the powder, except for the granules A of spray-dried lactose which gave a greater relative volume. (Fig. 13). Comparatively greater relative volume values were found for the compacts of granules A when compared with granules B. Spray-dried lactose show this behaviour quite clearly, Fig. 13. The diffferences in relative volume were diminished as the $F_{A}$ increased.

\section{DISCUSSION}

By using solvents and non-solvents to form granules it was intended to separate the effect of surface tension forces, with nonsolvents, and surface tension followed by crystal bridging with solvents. Binding agents were not used.

\section{Effect of granulating liquid}

The efffect of granulating liquid on the strength of tablets shows a number of trends. When using a non-solvent the tablets 
formed from granules appeared to be weaker than those formed from the original fine powder. With solvents the tablets were stronger than when non-solvents were used, and where the solubility of the substance was high, as for lactose in water, the tablets formed from granules were stronger than the tablets formed from the powder, with the exception of hexamine. This also applied to sulphadiazine which was poorly soluble in acetone and these soft granules tend to break down to the powder under compression, and as the force lost to the die wall at the higher pressure is less with granules than with the powder it indicates that area in contact with the die wall is less. Since less shearing of the surfaces in contact takes place between granules and the die wall, a weaker tablet results. This can be seen from the lower $\mathrm{Fd}$ values but the difference, however, is not great.

When granulating with a solvent hard granules result, due to crystalline bridges being formed between particles on drying. In addition the solvent will tend to remove surface defects and cracks, and this will increase the resistance of the crystal to deformation and fregmentation (Marsh, 8). This agrees with Huffine (9) that this would reduce the strength of the compact with a compact formed from the original powder. However, when the force is sufficiently large, fragmentation probably occurs at the crystal bridges exposing fresh surfaces for rebonding to form stronger tablets. The force at which this occurs appears to depend upon the substance being compressed, but it appears at the higher pressure used, tablets prepared from the granules A gave the stronger tablets.

The general tendency to result in a stronger compact when prepared from granules A, compared to granules B is accompanied by the greater relative volume for the compacts from granules A, In other words the relative density of granules B compacts is greater than compacts prepared from granules A. This improvement of relative density however, is not reflected in an corresponding increase in strength. As the force of compaction is increased the density of packing of the granules increases to a greater extent 
than does the granules A. However, the strenght of the bond between the particles is less and the total strength of the compact is less.

\section{Effect of granule size}

The granules B showed very little effect of the granule size - within the size range examined - on the strength of the tab. lets formed from them. Since the granules were soft and easily broken down, this could be expected. This applied also to sulphar diazine granulated with acetone as the solubility is probably too low to affect the flaws in the crystals.

The granules $\mathrm{A}$ of hexamine and spray-dried lactose produced the stronger tablet from the smaller granules in a similar manner to that found for crystals by Shotton and Ganderton (6). Granules A of aspirin did not show this effect, and this is probably due to fracture of the tablets taking place around the crystals, Shotton and Ganderton (7).

The effect of granule size on the strength of tablets is the inverse of the friction losses at the die wall. The force lost to the die wall for hard granules increases with the granule size for granules A except in the case of aspirin. The greater loss to the die wall by the larger granules A would also imply that there is a greater retardation of the punch movement so that the bottom of the tablet is less compressed. This could be brought about by the granules below and so transmitting a high radial force to the die wall. The crushing strength of the tablet would be dependent upon the least compressed zone. Therefore the tablets from granules are weaker.

\section{S U M M A R Y}

Solvents and non-sovents have been used to granulate aspirin, hexamine, sulphadiazine and spray-dried lactose. Granules prepared with solvents as a granulating liquid are the harder due to the formation of crystal bridges. When such granules are compressed 
the tablets compressed from granules prepared with solvents are stronger even though the porosity was greater. The harder granules offer a greater resistance to compression as shown by the force lost to the die wall, but fracture of the crystal bridges and re-bonding of the fresh surfaces would account for the greater strength.

\section{Ö Z E T}

Aspirin, hekzamin, sulfadiazin ve spray-dried laktozun granülasyonunda solvan ve non solvanlar kullanıldı. Granülasyon sıvisı olarak "solvan»lar kullanıldığında, kristal köprülerin olușması nedeni ile, elde edilen granüleler daha serttir. Bu tip granülelerden basılan tabletler, porozitenin büyük olmasina rağmen daha kuvvetlidirler. Daha sert olan granüleler, yuva cidarlarında kaybolan kuvvetlerin büyüklüğüinden de takip edilebileceği gibi basıma daha büyük bir rezistans göstermektedir. Fakat kristal köprülerinin çatlaması ve neticede açılan taze yüzeylerin yeniden bağlanması tabletlerde daha büyük bir mekanik dayanıklı̆ga sebep olmaktadir.

RE FERA N C E S

1 - Rumpf, H. : "Agglomeration" (ed. Knapper W.A.), 379, (1962).

2 - Seth, P. and Münzel, K. : Pharm. Ind., 21, 417, (1959).

3 - Jaffe, J. and Foss, E. : J. Amer. Pharm. Assoc., (Sci. Ed), 48, 26, (1959).

4 - Shotton, E. and Rees, J. : J. Pharm. 18, 1608, (1966).

5 - Ganderton, D. and Selkirk, A.B.: J. Pharm. Pharmac. 22, 345, (1970).

6 - Shotton, E. and Ganderton, D. : J. Pharm. Pharmac., 12, Suppl,, 87T - 92T (1960-a).

7 - Shotton, E. and Ganderton D. : Ibid., 12, 93T, (1960-b).

8 - Marsh, D. M. : Philos. Mag. 5. 1197, (1960).

9 - Huffine, C. L. : Ph. D. Thesis, Columbia University, (1953). 